\title{
Pengaruh Model Pembelajaran Multiple Intelligence Untuk Meningkatkan Teaching Efficacy Belief Dan Aktualisasi Diri Mahasiswa
}

\author{
Aswendo Dwitantyanov \\ STKIP Muhammadiyah Sorong \\ aswendopsi@gmail.com
}

\author{
Raisa Anakotta \\ STKIP Muhammadiyah Sorong \\ shasa_anakotta@yahoo.com
}

\begin{abstract}
This research tries to examine the influence of multiple intelligence based learning towards university students' teaching efficacy belief and self actualization of STKIP Muhammadiyah Sorong. The subject of this research is the 40 university students from Physical Education, Health and Recreation (PJKR) and English Education Program of STKIP Muhammadiyah Sorong which is consist of 20 in each control and experiment group. This is quasi experimental research with randomized pre-post test control group design and uses parametric test (t-test) for the technique of data analysis. The instrument of this research is analyzed by using TEB-AD scale with the coefficient cronbach's alpha 0,829. The result of this research shows that there is influence between multiple intelligence based learning towards TEB-AD score scale. The average of TEB-AD score scale in experiment is higher than control group, and there is significance differentiation of experiment rather than control group (te > ttabel $=0,338>-2,334$ ). So, the multiple intelligence based learning can be one of learning model which is effective to improve students' teaching efficacy belief and self actualization.
\end{abstract}

Keywords: Multiple Intelligence, Teaching Efficacy Belief, Self-Actualization.

\begin{abstract}
Abstrak: Penelitian ini berusaha untuk mengkaji pengaruh model pembelajaran multiple intelligence untuk meningkatkan teaching efficacy belief dan aktualisasi diri mahasiswa STKIP Muhammadiyah Sorong. Subjek penelitian ini adalah 40 mahasiswa Program Studi PJKR dan Program Studi Pendidikan Bahasa Inggris yang terdiri dari 20 mahasiswa di kelas kontrol dan 20 mahasiswa di kelas eksperimen. Jenis penelitian ini adalah penelitian quasi eksperimen dengan randomized pre-post test control group design. Penelitian ini menggunakan parametric tes (t-tes) dalam menganalisis datanya. Instrument dalam penelitian ini dianalisis dengan menggunakan skala TEB-AD dengan koefisien cronbach alfa sebesar 0,829. Hasil penelitian ini menunjukkan bahwa terdapat pengaruh antara multiple intelligence terhadap skor skala TEB-AD. Rata-rata TEB-AD dalam kelas eksperimen lebih tinggi dari pada nilai di kelas kontrol (te $>$ ttabel $=0,338>-2,334$ ). Dengan demikian, model pembelajaran multiple intelligence dapat menjadi salah satu model pembelajaran yang efektif untuk meningkatkan teaching efficacy belief dan aktualisasi diri mahasiswa.
\end{abstract}

Kata kunci: Multiple Intelligence, Teaching Efficacy Belief, aktualisasi diri

\section{Pendahuluan}

Pengembangan dan aktualisasi diri individu dalam pendidikan menjadi suatu alternatif untuk mempersiapkan individu menghadapi dunia kerja yang kompleks. Di sisi lain, pendidikan selalu menyesuaikan dengan kemajuan peradaban serta pola berpikir masyarakat. Hal ini membuat pendidikan bergerak dinamis dan berubah seiring waktu. Perubahan di dalam pendidikan ini menuntut guru untuk dapat lebih mengembangkan kemampuannya agar dapat menciptakan iklim 
pembelajaran yang up to date. Dalam hal ini termasuk calon guru yang sedang menempuh pendidikan tinggi.

Teaching efficacy belief berkaitan erat dengan keyakinan seorang guru untuk menjalankan peranannya dalam proses belajar mengajar dan menandakan level kemampuan dirinya sendiri. ; Bandura, 1986). Studi empiris mengenai peranan teaching efficacy belief menunjukkan bahwa kemampuan ini menjadi prediktor utama kompetensi guru dan berhubungan dengan komitmen untuk mengajar seefektif mungkin (Ross, 1998; Goddard dkk, 2000; Labone, 2004, Wheatley, 2005). Seorang guru yang memiliki teaching efficacy belief yang tinggi dapat lebih bersikap fleksibel dan menunjukkan tingkat kepuasan bekerja yang tinggi serta memiliki resiliensi yang cukup tinggi dalam rentang karirnya.

Aktualisasi diri berkaitan dengan ketepatan dalam menempatkan dirinya sesuai dengan kemampuan berdasarkan kemampuan pribadi di lingkungan sekitar (Bandura, 1997; Maslow, 1998). Pada guru, kemampuan ini berkaitan erat dengan memaksimalkan potensi yang dimiliki untuk mengembangkan metode pembelajaran untuk mencapai kepuasan belajar siswa yang maksimal (Fox, 2012). Untuk itu, aktualisasi guru semestinya dikembangkan sejak dini untuk menciptakan iklim belajar mengajar yang efektif serta efisien (Coble \& Hounshell, 1972).

Semakin berkembangnya ilmu pengetahuan dan pendidikan sudah tentu menuntut para guru dan calon guru untuk dapat mengembangkan peserta didik dengan lebih inovatif tidak hanya secara kognitif tetapi juga secara emosional dan psikomotorik. Dengan tiga kemampuan inilah seorang peserta didik diharapkan dapat memasuki dunia di luar sekolah dengan kesiapan (Bloom dkk, 1956). Dengan memfasilitasi peserta didik melalui model pembelajaran multiple intelligence diharapkan siswa dapat memperoleh pemahaman belajar yang luas dan bertanggung jawab atas pengetahuan yang dimilikinya.

Konsep model pembelajaran multiple intelligence memfasilitasi dan mengasah kemampuan problem solving, conceptual thinking, analytical thinking, body kinesthetic intelligence, linguistic aspect, intrapersonal, dan interpersonal skill (Howard, 1983 dalam Gilman, 2012). Di dalam penerapannya metode ini dapat direalisasikan dalam bentuk cerita, penyelesaikan masalah, berpikir secara reflektif serta kritis terhadap materi ajar, pengamatan mendalam terhadap materi ajar, memunculkan pertanyaan efektif, pendampingan diskusi kelompok yang dinamis untuk melihat kemampuan komunikasi siswa, kerjasama, serta kemampuan menjalin responsibilitas.

Dengan menerapkan model multiple intelligence diharapkan dapat menciptakan atmosfer belajar yang lebih proaktif dan efektif mengasah potensi peserta didik. Penerapan multiple intelligence pada calon pengajar atau guru diharapkan dapat menjadi model contoh untuk 
menciptakan suasana kelas yang kondusif dan membangkitkan efikasi guru dalam mengajar serta mengasah kemampuan guru untuk mengaktualisasikan potensi yang dimilikinya secara personal.

\section{Metode Penelitian}

Penelitian ini adalah penelitian eksperimen dengan desain kuasi eksperimen dengan desain, yaitu pre-posttest control group design (Shadish, Cook, \& Campbell, 2002) dengan cakupan populasi adalah mahasiswa program studi Penjaskesrek dan Bahasa Inggris di STKIP Muhammadiyah Sorong yang terdiri atas laki-laki maupun perempuan. Teknik sampling dalam penelitian ini adalah stratified random sampling yaitu cara pengambilan sampel dengan memperhatikan strata (tingkatan) dalam populasi. Strata yang dimaksudkan dalam penelitian ini adalah pemilihan kategori berdasarkan kelas (kelompok) yang sedang diambil oleh mahasiswa tersebut. Randomisasi dilakukan untuk memilih kategori kelas yang akan dipilih sebagai kelompok eksperimen dan kontrol. Penelitian akan dilakukan di kampus STKIP Muhammadiyah Sorong sesuai waktu yang telah ditetapkan.

Penelitian ini dilakukan diawali dengan survey awal untuk meninjau model pembelajaran yang diterapkan dan diperoleh mahasiswa selama ini. Kemudian, peneliti melakukan randomisasi terhadap kategori kelas yang akan dijadikan kelompok eksperimen dan kontrol. Setelah itu, peneliti melakukan screening sekaligus berguna sebagai data skor pretest sampel terpilih. Setelah dilakukan pretest, kemudian perlakuan diberikan kepada kelompok eksperimen yaitu dengan menerapkan model pembelajaran multiple intelligence, sedangkan kelompok kontrol tidak diberikan perlakuan. Setelah perlakukan diberikan, kemudian kedua kelompok diberikan posttest untuk melihat perubahan yang terjadi pada masing-masing kelompok eksperimen dan kontrol.

Pengumpulan data dalam penelitian ini menggunakan skala psikologiyang dibuat berdasarkan dimensi efikasi Bandura (1997) dan aktualiasi diri yang dikembangkan dari aspek-aspek aktualisasi diri yang dikemukakan oleh Maslow (1998). Skala ini diberi nama TEB-AD. Skala ini menggunakan model likert dengan empat kategori jawaban yaitu: Sangat Sesuai (S), Tidak Sesuai (TS), dan Sangat Tidak Sesuai (STS) yang dikembangkan sebelum proses penelitian dimulai dan telah melalui uji validitas serta reliabilitas (Azwar, 2003). Skala TEB-AD telah melalui uji validitas dan reliabilitas dengan koefisien cronbach's alpha sebesar 0,829.

Pengujian hipotesis dalam penelitian ini menggunakan teknik statistik parametrik uji-t dua sampel independen (independent Sample t-test) dan uji berpasangan (paired sample t-test) yang telah memenuhi syarat parametrik yaitu normal dan homogen. 


\section{Hasil dan Pembahasan}

\subsection{Hasil Penelitian}

Alat Ukur yang digunakan dalam penelitian ini adalah skala psikologis. Skala penelitian ini terdiri atas skala teaching efficacy belief dan skala aktualisasi diri. Jumlah item yang diharapkan dari penelitian ini adalah 20 dengan asumsi semakin banyak jumlah item suatu skala pengukuran maka objektivitas pengisi skala semakin kecil. Teaching Efficacy Belief terdiri atas 3 aspek, yaitu: Level, generality, dan strength (Bandura, 1997). Skala Teaching Efficacy Belief diadaptasi dari penelitian yang dilakukan oleh Catherine M. Aurah dan Tom J. McConnell. Di dalam jurnal penelitian yang berjudul "Comparative Study on Pre-Service Science Teachers' Self-Efficacy Beliefs of Teaching in Kenya and the United States of America" dilaporkan koefisien cronbach's alpha skala teaching efficacy belief adalah 0,90 ( Aurah \& McConnell, 2014).

Skala aktualisasi diri dalam penelitian ini diadopsi dari pengembangan skala aktualisasi diri oleh Alvin Jones dan Rick Crandall. Skala aktualisasi ini didasarkan atas 4 aspek psikologis yaitu penolakan terhadap penyeragaman, penerimaan diri, minat sosial, dan kreativitas (Maslow, dalam Koswara, 1991). Skala aktualisasi diri memiliki koefisien cronbach's alpha yaitu 0,69 (Jones \& Crandall, 1991). Total item rancangan skala teaching efficacy belief dan aktualisasi diri adalah 39 butir item, yang terdiri dari 24 butir item skala teaching efficacy belief dan 15 butir item skala aktualisasi diri. Skala tersebut kemudian dilabelisasi dengan nama skala TEB-AD dan akan diuji cobakan terhadap individu-individu dengan karakteristik yang serupa dengan subjek penelitian.

Uji coba dilakukan terhadap 40 individu untuk mendapatkan koefisien cronbach's alpha. Dari hasil uji coba pertama diperoleh koefisien cronbach's alpha yaitu 0,829. Skala TEB-AD ini menggunakan skala Likert dengan empat kategori jawaban, yaitu poin 1, poin 2, poin 3, dan poin 4 dengan menggunakan butir soal favorable dan unfavorable. Alasan tidak digunakannya pilihan tengah pada skala efikasi diri akademik yaitu bahwa pilihan tengah dapat menimbulkan kecenderungan central tendency effect bagi subjek yang ragu-ragu atas pilihan jawabannya serta untuk melihat kecenderungan subjek pada salah satu kutub jawaban (De Vellis, 1991).

Berdasarkan hasil uji coba skala TEB-AD terdapat 20 item yang memenuhi syarat dan 19 item yang gugur atau tidak memenuhi syarat. Butir item skala TEB-AD juga melalui professional judgement sehingga konten item skala diharapkan relevan dengan norma yang berlaku di Indonesia terkhusus di Sorong, Papua Barat. Hasil uji coba alat skala ditabulasi dan dianalisis untuk mengetahui validitas item dan reliabilitas skala. Validitas item ditunjukkan dengan indeks daya beda item $\left(\mathrm{R}_{\mathrm{ix}}\right)$ dan reliabilitas alat ukur ditunjukkan oleh koefisien alfa $(\alpha)$. Metode pengujian menggunakan corrected Item-Total Correlation. Dari perhitungan diperoleh koefisien cronbach's alpha sebesar 0,829. 
Dari output di atas bisa dilihat pada Corrected Item-Total Correlation, inilah nilai korelasi yang didapat. Nilai ini kemudian kita bandingkan dengan nilai $r$ tabel, $r$ tabel dicari pada signifikansi 0,05 dengan uji 2 sisi dan jumlah data $(n)=39$ maka didapat $r$ tabel sebesar 0,316. Dari hasil analisis dapat dilihat bahwa untuk item $1,3,4,5,6,9,10,11,12,17,18,19,24,26,28,29,33,38,39$ nilai $r$ kurang dari 0,316 , maka dapat disimpulkan bahwa butir instrumen tersebut tidak valid atau dinyatakan gugur. Sedangkan, pada item-item lainnya nilainya lebih dari 0,316 , sehingga dapat disimpulkan bahwa butir instrumen tersebut valid. Oleh karena itu, ada 20 item yang dinyatakan valid secara statistik $(\alpha=0,829)$.

Penelitian dilaksanakan di Program Studi PJKR dan Bahasa Inggris di lingkup STKIP Muhammadiyah Sorong dengan menetapkan calon subjek penelitian yaitu mahasiswa tahap akhir (semester 5-7). Mahasiswa yang dikenakan survey awal sejumlah 40 orang. Setelah diberi pretest kemudian dilakukan kategorisasi sesuai norma yang telah ditetapkan. Skor mahasiswa dikategorikan kedalam tiga kelas, yaitu tinggi, sedang, dan rendah. Kontinum ini terdiri dari tiga jenjang yang bergerak dari rendah ke tinggi.

Skala TEB-AD terdiri atas 20 item yang masing-masing skor berkisar dari 0,1,2,3. Skor tertinggi yang mungkin diperoleh adalah $60(3 \times 20)$ dan skor terendah yang mungkin diperoleh adalah 0 (0x20), sehingga rentang skor yaitu sebesar 60 (0-60). Nilai rataan hipotetiknya adalah 30 $(\mu=60 / 2)$. Rentang skor dibagi dalam enam standar deviasi, sehingga diperoleh 10 (60/6). Dengan $\mathrm{SD}=10(60 / 6)$, maka kategorisasi normatif skor adalah sebagai berikut:

Tabel 1. Gambaran Kategorisasi Kelompok Eksperimen dan Kontrol

\begin{tabular}{lll}
\multicolumn{1}{c}{ Rumus } & \multicolumn{1}{c}{ Skor } & \multicolumn{1}{c}{ Kategori } \\
\hline$X<(\mu-S D)$ & $X<20$ & Rendah \\
$(\mu-S D) \leq X<(\mu+S D)$ & $20 \leq X<40$ & Sedang \\
$(\mu+S D) \leq X$ & $40 \leq X \leq 60$ & Tinggi \\
\hline
\end{tabular}

Calon subjek diperoleh dari kategori yang sedang dan rendah. Jadi, diperoleh 40 subjek. Kemudian subjek di acak untuk menjadi kelompok eksperimen dan kontrol berdasarkan kelas (ruangan). Ruangan 1 sebagai kelas eksperimen dan Ruangan 2 sebagai kelompok kontrol. Tidak ada mortalitas dalam kedua kelompok penelitian selama proses penelitian berlangsung hingga selesai.

Pretest untuk kedua kelompok, yaitu kelompok eksperimen dan kontrol. Subjek pada penelitian ini sejumlah 20 orang pada kelompok eksperimen dan 20 pada kelompok kontrol. Subjek dipilih dari kategori yang sedang dan rendah, sehingga diperoleh masing-masing kelompok eksperimen dan kontrol terdiri dari 20 mahasiswa. Uji normalitas data menggunakan Lilliefors 
Technique yang merupakan pengembangan dari teknik kolmogorov-smirnov untuk jumlah subjek sedikit atau dalam asumsi kurang dari 200 subjek yang diteliti. Dari hasil analisis data terlihat bahwa asumsi signifikansi data adalah 0,60 ( > 0,05), sehingga dapat dikatakan bahwa data terdistribusi secara normal. Data juga dikatakan homogen karena memenuhi persyaratan pada levene test, yaitu bahwa signifikansi $0,935(>0,05)$ yang artinya varians masing-masing kelompok sebelum perlakuan adalah homogen. Hal ini berarti data terdistribusi secara normal dan homogen.

Berdasarkan analisis data yang diperoleh pada pretest dan posttest diperoleh informasi bahwa sebelum perlakuan pada kedua kelompok (eksperimen dan kontrol) adalah p sebesar 0,316. Oleh karena nilai $\mathrm{p}=0,189>0,05$ dan nilai te sebesar 1,336 < ttabel sebesar 1,686 $(\mathrm{dF}=38)$, maka hal ini menunjukkan bahwa tidak ada perbedaan yang signifikan antara kedua kelompok sebelum diberikan perlakuan.

Hasil perhitungan menggunakan paired sample t-test juga digunakan untuk menguji apakah ada perbedaan skor efikasi diri akademik mahasiswa yang signifikan sebelum dan sesudah perlakuan pada kelompok eksperimen. Berdasarkan hasil perhitungannya diperoleh informasi bahwa bahwa ada perrbedaan skor sebelum dan sesudah sebesar 16,30. Hal ini menunjukkan bahwa skor efikasi diri akademik sesudah perlakuan pada kelompok eksperimen lebih tinggi dibandingkan sebelum perlakuan dengan nilai $\mathrm{p}=0,000$ dan $\mathrm{t}_{\mathrm{e}}$ sebesar $-21,610$. Nilai Ttabel pada signifikansi 0,05:2 =0,025 (uji 2 sisi) dengan $\mathrm{dF}=19$ adalah $-2,093$. Oleh karena $-\mathrm{t}_{\mathrm{e}}<-\mathrm{t}_{\text {tabel }}(-$ $21,610<-2,093)$ atau $t_{e}>$ ttabel $(21,610>2,093)$ serta $p=0,000<0,05$, maka hasil tersebut menunjukkan bahwa ada perbedaan signifikan antara skor efikasi diri akademik sebelum dan sesudah perlakuan pada kelompok eksperimen.

Selain itu terlihat nilai $t_{e}$ adalah sebesar $-6,779$ dan signifikansi 0,000 . Nilai Ttabel pada signifikansi 0,05: 2 (uji 2 sisi) dengan $\mathrm{dF}=19$ adalah 2,093, maka hasil tersebut menunjukkan bahwa ada perbedaan antara skor efikasi diri akademik mahasiswa kelompok kontrol pada sebelum dan sesudah perlakuan. Berdasarkan data, terlihat perubahan (peningkatan) skor pada kelompok kontrol, namun dapat diasumsikan kenaikan pada kelompok kontrol tidak sebanding dengan kenaikan yang ditunjukkan oleh kelompok eksperimen. Untuk mendapatkan informasi lebih lanjut, peneliti melakukan analisis independent sample t-test menggunakan gain score atau dengan membandingkan skor selisih antara pretest dan posttest yang diperoleh kelompok eksperimen dan kontrol. Kelompok eksperimen yang sebelumnya atau dalam pretest memiliki rataan perolehan skor yang sebanding dengan kelompok kontrol juga mengalami peningkatan skor antara pretest dan posttest. Peningkatan skor ini memiliki rataan sebesar 6,3 sedangkan pada kelompok eksperimen sebesar 16,3. 


\subsection{Pembahasan}

Jelas bahwa ada efek pengulangan test pada subjek kedua kelompok, sehingga terjadi peningkatan pada skor posttest. Untuk melihat efektivitas perlakuan dapat diukur dengan membandingkan skor selisih atau gain score antara kelompok eksperimen dan kontrol. Gain score adalah skor selisih yang terjadi antara pretest dan posttest. Dua kelompok ini masing-masing mengalami peningkatan rataan skor dari pretestnya atau peningkatan antara dua kelompok ini tidak signifikan. Kelompok eksperimen $(\mathrm{KE})$ memiliki perubahan $(\mathrm{M}=16,3000)$ dibandingkan kelompok kontrol $(\mathrm{KK})$ yaitu sebesar $\mathrm{M}=6,3000$. Hasil analisis menunjukkan bahwa data dapat dikatakan homogen $(\mathrm{F}=0,942 ; \mathrm{p}>0,05)$ artinya tidak ada varians antara kelompok eksperimen dan kontrol. Oleh karena data kita terasumsi homogen, maka terlihat bahwa ada perbedaan pada taraf $1 \%(\mathrm{t}=8,355 ; \mathrm{p}<0,01)$, maka dapat dikatakan perlakuan yang diberikan kepada kelompok eksperimen adalah signifikan, dan terjadi perubahan yang signifikan pada kelompok eksperimen dibandingkan kelompok kontrol $\left(\mathrm{t}_{\mathrm{e}}>\mathrm{t}_{\text {tabel }}=0,338>-2,334\right)$.

Berdasarkan hasil analisis data, maka hipotesis yang diajukan dapat diterima yaitu ada perbedaan skor TEB-AD pada kelompok eksperimen sebelum dan sesudah perlakuan. Skor TEBAD kelompok eksperimen sesudah perlakuan lebuh tinggi dibandingkan sebelum perlakuan, hal ini berarti $\mathrm{H}_{1}$ diterima, dan sebagai kesimpulan ada pengaruh positif model pembelajaran multiple intelligence terhadap Teaching Efficacy Belief dan Aktualisasi Diri Mahasiswa STKIP Muhammadiyah Sorong.

Berikut adalah grafik perubahan pada kelompok eksperimen dan kontrol.

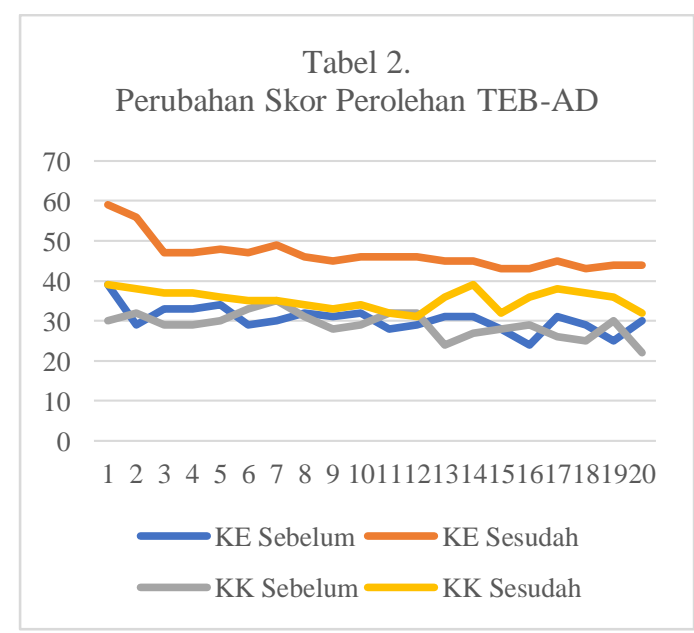

Kenaikan skor pada kelompok eksperimen sebelum dan sesudah perlakuan selain karena adanya model pembelajaran multiple intelligence, bisa juga disebabkan oleh faktor-fakotr 
individual yang tidak dapat dikontrol secara penuh oleh peneliti. Hal ini disebabkan kompleksnya dinamika psikologis manusia dan beragamnya aktivitas yang bisa mengubah skor pada subjek bersangkutan, sebagai contoh plilihan program televisi yang ditonton, persuasi sosial dari lingkungan sekitar tempat tinggal, dan fakotr lain yang di luar jangkauan peneliti.

Soemanto (1998) menambahkan terdapat beragam faktor individual yang menyebabkan terjadinya perbedaan efektivitas dalam belajar, misalnya kematangan dan kondisi kesehatan fisik serta psikologis. Selain itu, individu sebagai manusia lahir dengan sejumlah potensi hereditas yang dibawa dari orangtuanya melalui kromosom (Soemanto, 1998). Potensi bawaan ini turut berperan dalam perkembangan dan proses belajar individu, misalnya inteligensi dan fungsi fisiologis lainnya.

Potensi hereditas ini berinteraksi dengan pembelajaran dari lingkungan dalam perkembangan individu. Perbedaan kemampuan individu yang menimbulkan perbedaan fluktuasi efikasi diri akademik bisa disebabkan oleh potensi hereditas yang dibawa secara biologis. Selain faktor hereditas, terdapat sejumlah faktor lingkungan seperti stimulus dalam belajar, kesehatan individu, konsentrasi, keberartian materi, dan sebagainya yang berada di luar kontrol penelitian, tetapi turut serta berperan dalam mempengaruhi internalisasi materi pelatihan, sehingga terjadi perbedaan fluktuasi skor perolehan antara subjek satu dengan lainnya.

Perubahan skor pada kelompok kontrol terjadi dalam konteks yang kecil. Perubahan yang terlihat dapat disebabkan oleh adanya proses historis dan maturasi. Maturasi adalah proses perubahan yang terjadi normal seiring berjalannya waktu (Azwar, 1998). Maturasi menimbulkan perubahan-perubahan yang dapat mempengaruhi skor perolehan TEB-AD baik kearah peningkatan maupun penurunan. Proses historis merupakan kejadian-kejadian khusus yang terjadi di luar perlakuan selama rentang pretest dan posttest yang dialami oleh subjek pada kelompok kontrol. Dalam penelitian terhadap subjek manusia atau dalam hal ini penelitian kuasi eksperimen, proses historis tidak sepenuhnya dapat dikontrol dan terjadi di luar kehendak peneliti, tetapi proses ini adalah sesuatu yang wajar terjadi dalam penelitian-penelitian psikologis yang menempatkan manusia sebagai subjek penelitiannya.

\section{Simpulan dan Saran}

\subsection{Kesimpulan}

Berdasarkan uraian di atas, dapat disimpulkan bahwa model pembelajaran multiple intelligence memiliki pengaruh dalam meningkatkan teaching efficacy belief dan aktualisasi diri mahasiswa (TEB-AD). Terlihat bahwa skor perolehan skala TEB-AD yang mencerminkan skor teaching efficacy belief dan aktualisasi diri dari kelompok eksperimen lebih tinggi dibandingkan 
dengan kelompok kontrol. Terjadi juga peningkatan skor yang signifikan pada kelompok eksperimen sebelum dan sesudah diberi perlakuan berupa model pembelajaran teaching efficacy belief. Hasil analisis data penelitian menunjukkan bahwa hipotesis satu $\left(\mathrm{H}_{1}\right)$ dalam penelitian ini dapat diterima.

\subsection{Saran}

Dalam rangka turut menyumbangkan pemikiran yang berkenaan dengan model pembelajaran multiple intelligence, maka dapat disarankan hal-hal sebagai berikut.

a) Bagi peneliti sebaiknya lebih mengembangkan wawasannya dalam hal pengembangan model pembelajaran multiple intelligence secara lebih spesifik dalam setiap proses pembelajaran.

b) Selain itu, peneliti juga berharap pada penelitian selanjutnya lebih mempertimbangkan kedalaman materi kajian dalam pelatihan dengan melakukan penekanan pada praktek dan aplikasi praktis untuk menerapkan prinsip-prinsip Multiple Intelligence.

c) Bagi mahasiswa sebaiknya lebih terlibat aktif dalam kegiatan pembelajaran dan bersifat antusias sehingga proses pembelajaran berjalan secara efektif dan efisien.

\section{Daftar Pustaka}

Alwisol. 2004. PsikologiKepribadian. Malang.Universitas Muhammadiyah Malang Press.

Azwar, S. 2003. PenyusunanSkalaPsikologi. Yogyakarta.PustakaPelajar.

Bandura, A. 1986. Social Foundation of Thought and Action: A Social Cognitive Theory. New York: Prentice Hall.

Bandura, A. 1997. Self Efficacy: The Exercise of Control. New York. W. H. Freeman and Company.

Bassi, M., A.D. Fave, dan F. Massimini. 2007. Academic Self-Efficacy Beliefs and Quality of Experience in Learning. Springer Science and Business Media. 36: 301-312.

Bloom, B., Englehart, Furst, Hill, dan Krathwohl. 1956. Taxonomy of Educational Objectives: The Classification of Educational Goals. Handbook I: Cognitive domain. New York: Longmans Green.

Boeree, C.G. 2004. Personality Theories. Yogyakarta: Primasophie.

Coble, C.R., danHounshell. 1972. Teacher Self-Actualization and Student Progress. Science Education. 56(3): 311-316.

Deci, E.L., dan Richard M.R. 2012. In Ryan, R.M. 2012. The Oxford Handbook of Human Motivation. Oxford: Oxford University Press. 267-285

Depdiknas. 2003. Undang-Undang RI Nomor 20 Tahun 2003 Pasal 40 Ayat 2, tentangSistem Pendidikan Nasional.

Fox, J.V.D. 2012. The Self-Actualizing Teacher. Improving College and University Teaching Journal. 13(3): 147-148.

Gilman, L. 2012. The Theory of Multiple Intelligences. Indiana. Indiana University.

Goddard, R.G., Wayne K.H., dan Woolfolk H. 2000. Collective Teacher Efficacy: Its Meaning, Measure, And Impact On Student Achievement. American Educational Research Journal. 37: 479-508. 
Goldstein, K. 1995. The Organism: A Holistic Approach to Biology Derived from Pathological Data in Man. New York. Zone Books.

Koswara, E. 1991. Teori-Teori Kepribadian. Bandung: PT. Eresco.

Labone, E. 2004. Teacher Efficacy: Maturing The Construct Through Research in Alternative Paradigms. Teaching and Teacher Education. 20: 341-359.

Maslow, A.H. 1998. Toward a Psychology of Being( $3^{\text {rd }}$ Edition). New Jersey. Willey and Sons.

Rogers, C.R., Lyon, Harold C, Tausch, dan Reinhard. 2013. On Becoming an Effective Teacher Person-centered Teaching, Psychology, Philosophy, and Diologues with Carl R. Rogers and Harold Lyon. London: Routledge.

Ross, J.A. 1998. The antecedents and consequences of teacher efficacy. In J. Brophy. Advances in research on teaching. Greenwich, CT: JAI Press. 7: 49-73.

Shadish, Cook, dan Campbell. 2002. Experimental and Quasi-Experimental Design for Generalized Causal Inference. Boston. Houghton Mifflin Company.

Smith, Mark K. (2002). Howard Gardner, multiple intelligences and education. In The encyclopedia of informal education. Boston. Harvard University Press.

Stein, M.I. 2014. Stimulating Creativity: Individual Procedures. London. Academic Press Inc. Ltd.

Wheatley, K.F. 2005. The Case for Reconceptualizing Teacher Efficacy Research. Teaching and Teacher Education. 21: 747-766.

Woolfolk, A., dan Davis. 2005. Teachers' Sense of Efficacy and Adolescent Achievement. In T. Urdan\& F. Pajares (Eds.). Adolescence and Education. 5: 117-137. Greenwich, CT. Information Age. 